\title{
A képernyô és a filmvászon hibridizációja: a videóchat és a videószelfi játékfilmes idézése (Remélem, legközelebb sikerül meghalnod ?, FOMO ? Megosztod és uralkodsz, Szép csendben)
}

\begin{abstract}
Absztrakt
A három kortárs magyar filmben azt vizsgálom, hogy a médiatechnológiák milyen szerepet játszanak a történetben az erôszak vagy visszaélés elkövetésében, dokumentálásában (rögzítésében) és bizonyításában. Az online mozgóképi telekommunikáció nemcsak a történet kibontakozásában vesz részt, hanem mozgóképi idézetként olyan intermediális aktusként fogható fel, mely a filmnarráció lehetôségeit is módosítja. A videóchat, a videószelfi és általában a számítógépes képernyô beemelése a játékfilmbe a filmvászon és a számítógépes képernyô mûködése közti különbségeket feszegeti, feltérképezi a szereplô narratív és digitális identitása közti határvonalat, valamint a fikciós teret kiterjeszti a hálózati térre, a történet idôbeli összefüggéseit összekapcsolja a hálózatiság szimultaneitásával.
\end{abstract}

\section{Szerzô}

Füzi Izabella 1976-ban született Kézdivásárhelyen. A Szegedi Tudományegyetem Elmélet és interpretáció programján szerzett doktori fokozatot irodalomtudományból. Jelenleg az SZTE Bölcsészettudományi Karán múködô Vizuális Kultúra és Irodalomelmélet Tanszék oktatója. Az Apertúra (www.apertura.hu) alapító felelôs szerkesztôje. Kutatásai a filmi és irodalmi történetmondás komparatív vizsgálatára, a retorika nyelvfilozófiai megközelítésére, a medialitás, a nézôi szubjektum megalkotottságának filmelméleti kérdéseire, a vizuális tömegkultúra történeti vizsgálatára terjednek ki. Ilyen tárgyú írásai tanulmánykötetekben és szakfolyóiratokban ( Literatura, Alföld, Holmi, Helikon, Metropolis, Apertúra) jelentek meg. Társszerzője a Bevezetés az epikai szövegek és a narratív film elemzésébe (Szeged, 2006) címú munkának. Önálló kötete (Retorika, nyelv, elmélet. Szeged, JATEPress) 2009-ben jelent meg. Számos könyv és szöveggyújtemény (Retorikai füzetek, Apertúra Könyvek) szerkesztője.

https://doi.org/10.31176/apertura.2021.16.4.5 


\title{
A képernyô és a filmvászon hibridizációja: a videóchat és a videószelfi játékfilmes idézése (Remélem, legközelebb sikerül meghalnod ?, FOMO ? Megosztod és uralkodsz, Szép csendben)
}

\begin{abstract}
A Remélem, legközelebb sikerül meghalnod (Schwechtje Mihály, 2018), hOMO Megosztod és uralkodsz (Hartung Attila, 2019) és a Szép csendben (Nagy Zoltán, 2019) hármasa az elmúlt évek magyar filmtermésében különleges konfigurációt alkot, hiszen mindhárom film a szexuális zaklatás vagy visszaélés (az elsô két esetben internetes zaklatással kiegészülố) témáját dolgozza fel. Mindhárom film tinédzserkörnyezetben játszódik olyan karakterekkel, akik a felnôtté válás küszöbén állva nem sok segítséget kapnak a felnôttektól vagy a társaiktól a traumák és az ôket elborító érzések feldolgozásában. Mindhárom film a rendezôk elsô nagyjátékfilmje, és mindhárom valamilyen sajátos narratív és/vagy képi megközelítést választ a téma narrativizálásában. A kritikák a filmek relevanciáját egyöntetűen a nemi erôszak és visszaélés kortárs diskurzusához képest pozicionálták. ${ }^{[1]}$ Ebben a tanulmányban egy másik szempontot szeretnék megvizsgálni, mégpedig azt, hogy a fiatalok által is használt kortárs médiatechnológiák milyen szerepet játszanak a történetben az erôszak vagy visszaélés elkövetésében, dokumentálásában (rögzítésében), bizonyításában és diskurzusában.
\end{abstract}

A Remélem-ben a két fôszereplô közti érzelmi viszony a videóchaten bontakozik ki, de az egyik fél digitálisan valaki másnak az identitását veszi fel, késôbb bosszúból az intim helyzetben a videóchaten rögzített képeket nyilvánossá teszi. A FOMÓ-ban a föszereplô egy vloggercsapat tagja, akiknek legkedvesebb idôtöltése a YouTube-ra szánt challange-videók készítése. A kontentgyártásban érvényesülő, fokozódó egymásra licitálás a szereplốt belehajszolja egy olyan nemi erôszakba, melyet a rögzítés céljából követ el. A Szép csendben az ellenpélda szerepét tölti be azzal, hogy visszautasítja az erôszak mozgóképi bemutatásának, bizonyításának kényszerét - és bár az áldozat készít egy hangfelvételt, aminek célja az elkövetés dokumentálása, a film a rögzítô és kommunikációs technológiák hatókörén kívül helyezi az erôszak által okozott trauma megélhetôségét és közölhetôségét.

A kortárs filmek mai történeteibe már egyre megkerülhetetlenebb azoknak az online kommunikációs technikáknak a beemelése, amelyek nemcsak a karakterek, hanem a nézók mindennapjait is alakítják. Ez annak a következménye, hogy a mozgóképkészítés, -közvetítés, terjesztés privilégiuma már nem korlátozódik a filmkészítôkre, hanem a mindennapi élet fontos eszközévé vált. A filmkészítés praktikus szempontjából pedig azt vonja maga után, hogy 【mivel a játékfilmes karakterek már nemcsak a fiktív térben tevékenykednek, hanem az online térben is [ 
létre kell hozni a vágóasztalon azt a digitális infrastruktúrát, mely a karaktereknek digitális identitást kölcsönöz (honlapok és felületek architektúrái, felhasználói profilok, stb.). A következókben a mozgóképi kommunikáció két múfaját vizsgálom: a magánszemélyek közti beszélgetésre használt videóchatet és a közösségimédia-felhasználásra készített videószelfit.

A mozgóképi kommunikáció történetében a videóchat úgy viszonyul az analóg filmhez, mint a telefon a fonográfhoz a hang technikai mediatizációjában. A fonográf és a kinematográf rögzítette a hangot, illetve a mozgóképet, így alkalmassá tette az eltolt, késleltetett, egyirányú kommunikáció céljaira. Az azonnali, egyirányú kommunikációt a rádió és a televízió élô músorai valósították meg, de az azonnali visszacsatolásra lehetôséget adó mozgóképi médiumra egészen napjainkig kellett várni.

$\begin{array}{lll}\text { kommunikáció } & \text { hang } & \text { mozgókép } \\ \text { késleltetett egyirányú } & \text { fonográf } & \text { kinematográf } \\ \text { azonnali egyirányú } & \text { rádió } & \text { televízió } \\ \text { azonnali kétirányú } & \text { telefon } & \text { videóchat }\end{array}$

A játékfilmes karakterek közti egyidejú kommunikáció tehát nem a videóchattel kezdôdött. A telefonbeszélgetés (a távirat mellett) a korai narratív filmben (Griffith egytekercseseiben) gyakran szolgált a gyors és gyakori helyszínváltás meghonosításának és magyarázatának diegetikus eszközeként. A párhuzamos szerkesztés egyik funkciója a diegetikus egyidejúség létrehozása, mely a beállításváltásnak nem a térbeli, hanem az idôbeli logikája mentén ad értelmet: a térbeli megszakítás hozza létre az egyidejûséget a helyek egymás utáni bemutatásával. ${ }^{[2]}$ A helyek ilyen (táv)kommunikációja a fiktív tér kiterjesztésének és az egyidejúség érzetének érzéki bemutatását eredményezi [a nézô, de nem a szereplôk számára[3]

A videóchat mint egyidejú mediatizált interakció a szereplők szintjén történik, mivel a láthatóság dimenzióját is bevonja a kommunikatív csereaktusokba. A videóchatelő szereplók helyzete a játékfilmben azért sajátos, mert ôk maguk is mozgóképek előállítóivá, közvetítôivé és nézôivé válnak, miközben filmezik magukat és nézik magukat és a beszélgetô partnerüket. Ez a helyzet nagyban különbözik attól, amikor a szereplôk moziban vagy tévében mozgóképet néznek. A videóchatelôkk tehát nem csupán a filmnézők megkettőződései, hanem az online kommunikáció részvevôi, ami által a diegetikus jelen idô és a diegetikus tér a szereplôk tevékenységén keresztül és ellenôrzése mellett megoszthatóvá válik. A telefonbeszélgetés klasszikus játékfilmes alkalmazása az egymástól távol lévố terek összekapcsolását segítette, a távolság áthidalását, a fiktív tér kiterjesztését olyan helyekre, melyek a szereplôk számára közvetlenül nem elérhetôek. ${ }^{\left[{ }^{4]}\right.} \mathrm{A}$ videóchat játékfilmes alkalmazásánál nemcsak a néző, hanem a szereplôk számára is hozzáférhetôvé válik a távoli tér és idô sajátos, vizuális és hang által történô intim megtapasztalása. A kétszemélyes magánbeszélgetések esetében a privát otthoni tér, illetve a személyes, intim tér megosztásának kezdeményezése a szereplốk hatáskörébe esik, megvalósulása azonban az online mozgóképi kommunikáció mediális keretei között lehetséges.

A videószelfi digitális megjelenése a webkamera tömeges elterjedéséhez kapcsolódik, mely a 
számítógép terét egycsapásra beemelte a hálózati térbe. ${ }^{[5]}$ Késôbb a mobiltelefonba szerelt szelfikamerák megjelenésével lehetôvé vált a mobilt hordozó testnek a hálózathoz kapcsolása. A privát, intim tér megosztása, a felvételek szerkesztetlensége, a gyakori közelképek a videóblogokhoz hasonló formai megjelenítést eredményeznek. Míg azonban a videóblogban a videó-én identitásának a megteremtése az epizódok sorozatában történik, gyakran önéletrajzi, narratív szituációba ágyazva, ${ }^{[6]}$ a videószelfi nem teszi szükségessé az ilyen típusú idôbefektetést. Lehet az azonnali kommunikáció része (élóben közvetített, mint a videóchat) vagy késleltetett, de az azonnali visszacsatolás a videóchattôl eltérôen általában más, nem mozgóképi formában történik.

Akárcsak az állóképes verziója, a videószelfi sem pusztán mobillal vagy webkamerával készített önportré(film), hanem a közösségi médiába való megosztás céljából készített (mozgó)kép, tehát a hálózati kommunikáció része, ,annak a képessége, hogy a digitális hálózatokra kapcsolt (mobil)eszközökkel fényképezzük le magunkat, hogy aztán ezt az öndokumentációt másokkal is megosszuk". [7] Misha Kavka meggyőzően érvel amellett, hogy a szelfi nemcsak az énünk meghosszabbítása a hálózati kommunikáció felületein, hanem a (deleuze-i értelemben vett) testgép asszamblázs része. Ahogyan a mobil az azt tartó kézben, a jellegzetes pózban a testhez kapcsolódik, az applikációkkal készített, filterekkel átszúrt, bizonyos keretezésekben és meghatározott pózokban feltünô szelfi-én egy technologizált test, mely nemcsak a fizikai környezetben, hanem egy újfajta, hálózatosított társadalmi mezôben is elhelyezi az ént. A szelfi „az én, a tér, a gép és a hálózat közt létrejövő komplex viszonyok együttese”, „a digitális eszközön átszûrt és a közösségi hálóra szánt testi én az ôt körülvevô térben”. ${ }^{[8]}$ Az önfilmezés a videószelfi esetében tehát kiegészül a csoporthoz tartozás vágyával, a hálózati identitáshoz kapcsolódó tekintet interiorizálásával - ez határozza meg a videószelfi társadalmi vetületét.

Mind a videóchat, mind a videószelfi esetében a felhasználó egyszerre több olyan pozíciót testesít meg, amelyek a hagyományos vizuális rezsimekben külön szubjektumokhoz kapcsolódtak [ egyszerre mozgóképkészítő és -befogadó, -előállító és -terjesztô, operatôr, színész és rendezô, világosító, berendezô, vágó, utómunkás, nézô és nézett. A legdrasztikusabb kihívást a nézô és a nézett egyesítése jelenti, ami a társadalmi viszonyok alapképletének számító „látni” és „látva lenni” kölcsönösségét egyetlen, meghasadt szubjektumhoz kapcsolja. ${ }^{[9]}$ Technikai értelemben erre elôször a 70-es években tömegesen elterjedô videókamera adott lehetôséget, mely az analóg filmfelvevőgéppel szemben (ahol szükségszerú az idôbeli eltolás a felvételkészítés és a megtekintés ideje között), lehetôvé tette az azonnali képfeldolgozást és -közvetítést. A tévé által bevezetett élő közvetítést a videómúvészet különbözô kísérletei radikalizálták, vagy fordították a visszájára. Bódy Gábor a kamerát szembefordította a vele összekapcsolt monitorral, így jött létre a „végtelen kép”, mely olyan végtelen regressziót nyitott meg, ahol a kép a kamera és a monitor közti megsokszorozódott terekben eltûnik. ${ }^{[10]}$ Lynda Benglis videóinstallációjában két arc mosódik egybe: az egyik a monitoron látható arc, és egy másik, élố arc, mely a monitoron lévố arcot utánozza. Miközben egymást kérdezik vagy parancsszavakat osztogatnak [, Most!”, „Ez most van?”, „Indítsd el a kamerát!” ]a rögzített és az „élô” arc közti különbség elmosódik. Rosalind Krauss 
szerint a videómúvészet „paradigmatikus esete a kamera és a monitor között zárójelezett, felfüggesztett test”. [11]

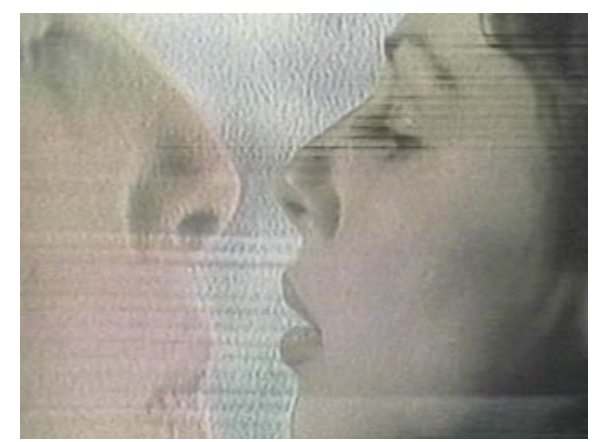

Lynda Benglis: Now (1973)

Míg a videómúvészet a tükörhelyzetet reflexív távolsággá alakítja (Lynda Benglis a saját monitorarcával veszekszik, vagy a monitoron megjelenô arcot szájon csókolja), a videószelfiben a szelfikamera és a digitális kijelző közti azonnali visszacsatolás által a felhasználói tapasztalatban a rögzítés egybeesik a megjelenítéssel, a szubjektum az objektummal, a nézô a nézettel. Ez a rövidzárlat a szereplô-színész, az operatôr és a nézői pozíció között a felügyelet, az ellenôrzés illuzórikus hatalmát kölcsönözheti a szelfizőnek, bár ennek az ára a mozgókép és a szubjektum önmagába záródása, melyben az objektív és szubjektív szemszög, a kamera elôtti és mögötti egybeesik. Ahogyan Ferencz-Flatz rámutat, bár a videónak lehet egy kihelyezett megszólítottja, aki a filmezés és pózolás célpontja, a tükörben ellenôrzött és módosított pózolás, az önfilmezés folyamatosan kibillenti a kommunikációt. [12]

Míg a digitális és mozgóképtechnikák feletti kontroll sajátos ágenciát biztosít a szereplők számára a fiktív világban, ez gyakran jár együtt a tehetetlenséggel és az áldozati szereppel. Ez történik legalábbis az olyan képernyőfilm-thrillerekben, mint az Unfriended: Dark Web (Stephen Susco, 2018), Keresés (Searching. Aneesh Chaganty, 2018) vagy a Profile (Timur Bekmambetov, 2018). A formailag nagyrészt a videóchatre alapozó mozgóképek egyben történetmesélô filmek is, melyek a képernyô és a filmvászon hibridizációjával kölcsönöznek a szereplôknek egyszerre játékfilmes és digitális identitást. A képernyőfilm jut a legmesszebbre ennek a hibridizációnak a kiaknázásában: itt a történések helyszíne a szereplôk által használt elektronikus kijelző(k), a szereplôk tettei a képernyőre korlátozódnak, identitásuk azoknak a digitális múveleteknek az effektusa, amelyeket a nézố beazonosít és felismer. A számítógépes monitor egy olyan operatív mezô, ahol a végrehajtott digitális múveletek (keresés, navigáció, online kommunikáció, megnyitás, törlés, stb.) a hálózat végtelen teréhez és örök jelenéhez való kapcsolódás eszközei, miközben a hálózat bejárt útvonalai a digitális szubjektum, identifikáció lehetôségét is kiváltják. A képernyőfilm nézôjét az applikációk múködésének az ismerete varrja be az elbeszélésbe, teszi a narratív kommunikáció címzettjévé.

A videóchat, a videószelfi és általában a számítógépes képernyô ilyen beemelése a játékfilmbe egy olyan intermediális aktusként is elgondolható, mely a filmvászon és az interfészként múködô képernyő közti különbségeket feszegeti, feltérképezi a szereplő narratív és digitális identitása közti határvonalat, valamint a fikciós teret kiterjeszti a hálózati térre, a történet idôbeli összefüggéseit 
összekapcsolja a hálózatiság szimultaneitásával. A szereplôk által létrehozott vagy használt mozgóképeknek a játékfilm testébe ágyazása, a mozgóképek mozgóképben való idézése a médiarivalizáció összefüggésében is vizsgálható. Paul Young Cinema dreams its rivals (2005) címú könyvében olyan hollywoodi filmeket elemez, melyek a játékfilm domináns helyzetét veszélyeztetố rivális médiumokkal (rádió, tévé, internet) foglalkoznak. ${ }^{[13]}$ A fôsodorbeli filmekben két stratégia különböztethetô meg: a videó, a számítógép, a virtuális valóság, az internet, a közösségi média, a videójáték, stb. vagy utópikus remények és elvárások tárgyaivá válnak, melyeket jelenleg nem tudnak teljesíteni, vagy félelmet keltô, horrorisztikus történetek szereplői (kísértetjárta tévékészülékek, halált hozó VHS-kazetták, a közösségi média mint a totális ellenôrzés eszköze).

Az általam vizsgált filmek nem tisztán ebbe a paradigmába sorolhatóak; a más médiumokkal való versengés nemcsak a film helyzetével kapcsolatos szorongást jelenítheti meg, hanem az új médiumok hatásainak bekebelezô kisajátítását és a film identitásának az újratárgyalását is célozhatja. Mivel ezekben a filmekben a történeteknek a nézői megalkotását a játékfilm narratív technikái közvetítik, a továbbiakban azt vizsgálom, hogy a digitális technikák használatának a megjelenítése a filmben milyen ütközési pontokat hoz létre a két médium között, hogyan helyezi át a fikciós film narratív lehetôségeit. A kérdés a továbbiakban tehát úgy tevôdik fel, hogy milyen módon keresztezi a mozgóképi telekommunikáció a fikció felépítését, mi a játékfilmes narráció és a mediatizált online interakció viszonya, és hogyan formálja át a játékfilmes karakterek identitását a digitális identitásuk.

\section{Remélem: a videóchat játékfilmes kisajátítása}

A Remélem 【akárcsak aFOMO [a közösségi média szocializációs szerepét alapvetônek tekinti a fiktív világ fiataljai esetében. A digitális mûveletek egyszerre teszik lehetôvé az identitások, avatárok, perszónák váltogatását, kreatív alakítását és az én - fôként a képeken keresztül történô [ tárgyiasítását, amikor a „képi énre” [14] vonatkozó, számszerúsíthetố figyelem(mennyiség) az identitás egyetlen támaszává és az önbizalom fokmérójévé válik. Beninek, aki a film egyik mellékszereplője, az a legnagyobb problémája, amikor a barátnôje a közösségi médiában szakít vele, hogy tönkreteszi az imidzsét; Adri arra büszke, hogy az üzenőfala „egy múalkotás”. A digitális „személyiség” (digital personhood) dramaturgiai megközelítése párhuzamot von az offline és az online identitások konstitúciója, rögzíthetôsége, tárolása és hozzáférhetôsége között. Erving Goffman munkájából [15] tudjuk, hogy az önprezentáció mindennapi dramaturgiai feladat, amelyben az alakítás célja a többiek befolyásolása, és olyan ismételhetô, elôre megszabott cselekvési minták szerint történik, melyeket (társadalmi) szerepeknek nevezhetünk. Különböző közönségek elôtt különbözô identitásokat viszünk színre (Goffman terminusaiban: mást mutatunk homlokzatként és mást hagyunk rejtve a színfalak mögött). Kerrigan és Hart ${ }^{[16]}$ viszont arra hívja fel a figyelmet, hogy a digitális interakciókban nemcsak felszaporodhat a szerepek, perszónák, maszkok száma a különbözô applikációk, platformok és használataik mentén, amelyeket nehéz 
egységesíteni, egyben tartani, hanem a rögzítés és tárolás eltérô lehetôségei miatt idôben is ugyanúgy problémás az identitás egységesítése, összefogása. Míg a sokféle temporális identitás az egyén élettörténetében csak az átmeneti, liminális fázisra jellemző a hagyományos társadalmakban, ami a beavatási rítusokon keresztül megélhetô és narrativizálható, addig a digitális személyiség különböző platformokra és applikációkra széttagolt részei nehezen vethetôk alá narratív tranzakcióknak, és technikai rögzíthetôségük és tárolhatóságuk folytán alkalmasak arra, hogy kiszivárogtassák (leakage).

A Remélem dramaturgiai szerkezete látványosan állítja ki a digitális és offline identitás közti folytonossághiányt, amikor a film 35. percében nézôpontot vált, és egy új fokalizátort léptet be az elbeszélésbe. Mindaddig Eszter, az angoltanárába szerelmes középiskolás lány rajongó, szerelmes szemén keresztül építettük fel a történetet, viszonyuk szöveges üzeneteken és fôkként a videóchaten keresztül bontakozott ki. A nézôpontváltással a történet elölrôl kezdôdik, és amikor Péter válik az események és értékelésük fokalizátorává, kiderül, hogy ő az, aki az angoltanárt digitálisan megszemélyesítette és Esztert manipulálta, mivel úgy érezte, hogy a lány figyelmét nem tudja másképpen tartósan magára irányítani. Miután a lány szakít az „angoltanár”-Péterrel (81. perc), és az osztálytársával kezd járni, Péter bosszúból elküldi Eszter riválisának a lány félmeztelen fotóit, melyeket korábban a videóchatelés alatt rögzített. A képek nyilvánosságra kerülése után az osztálytársak megvetése és online zaklatása öngyilkossági kísérletbe kergetik Esztert; ezután a közösségi médiába posztolt hírhez kapcsolódóan Eszter vetélytársának kommentjeként jelenik meg a film címe: „Remélem, legközelebb sikerül meghalnod ”. A két szereplői nézőpont szétszálazása és egymásutánisága felbontja a történet idejét: akárcsak a klasszikus példákban, $A$ vihar kapujában (Rashomon. Akira Kuroszava, 1950) és A lé meg a Lolában (Lola Rennt. Tom Tykwer, 1998), itt is ismétlődô elemeket kapunk, viszont a két verzió nem abban különbözik elsősorban, hogy „objektíven” mi történt, hanem az események pozicionálásában, ahogyan ezek a szereplôk lelki háztartásában elkönyvelődnek, és az ô érzelmi befektetésük felôl értékelôdnek. Míg az elsô verzióban az angoltanár (viszonyt) kezdeményezô közeledését Eszter vonzódásán és ragaszkodásán keresztül éljük át, a második verzióban Péter viszonzatlan érzései keretezik és magyarázzák a hamis identitást létrehozó manipulációt. Így nézóként rendre lehetôségünk nyílik arra, hogy az eseményeket mind Eszter, mind Péter lelki mozgatórugói felôl megtapasztaljuk. A film harmadik részében mindkét szereplői nézôpont egymás mellé helyezôdik, és bár kiderül, hogy Péter is ugyanúgy áldozata az iskolai zaklatásoknak, Eszter kétszeresen is áldozat: nemcsak a közösségi médiában elszenvedett megszégyenítés és kirekesztés miatt, amit átél, hanem a digitális személyiséglopás megtévesztett áldozata is - ez utóbbi a történet lezárulásával is Péter titka marad.

A történések kétféle cselekményesítése között a szinkronizációs pontokat többek között az ismétlődố telefonbeszélgetések, szöveges üzenetek, videóchatelések hozzák létre. Mindhárom telekommunikációs forma a jelen idô megosztásán, az azonnali és kölcsönös interakción alapszik. A Remélem egyszerre kreatív és a rivális médium erejét viszonylagosító gesztussal azonban szétszakítja az online telekommunikáció által összekötött pólusokat, és ezek újbóli összekapcsolása 
késleltetve, egymáshoz képest eltolva egyrészt a nézó feladata lesz, másrészt a játékfilmes narráció fennhatósága alá kerül. Elôször Eszter nézôpontjából bontakozik ki a történet, aztán Péter nézôpontjából, és már az ismétlés elsô jelei a nézôt arra sarkallhatják, hogy különbségeket és megfeleléseket keressen a két verzió között. (Amikor Eszter kiborul amiatt, hogy a rajongott személy másnap elköltözik az országból, Péter annak örül, hogy legalább a digitális térben közelebb kerülhetett a lányhoz [a filmidôben ezt egy fél óra eltolással tudjuk meg.) A nézôpontok eltolása a felhasználói tapasztalat felôl mutatja be a videóchatet: a beszéló fél számára csak az interfész hozzáférhetô, és az így létrejövô kommunikatív aktusok jelentését az általuk létrehozott kontextus és a használatuk határozza meg. Eszter a videóchat naiv felhasználója (az ô szerelmes tekintete a tanár fényképét és a manipulált hangot az idealizált személy jelenléteként olvassa), míg Péter kihasználja az online kommunikáció azon lehetôségét, hogy általa az identitás jelölói (a videóchat esetében: a név, a fénykép, az írott szöveg, a digitálisan manipulált hang(szín), a testi (táv)jelenlét) önkényesen össze- és szétkapcsolhatóak. Ennek ellenére azonban mindketten a médiumhasználat áldozatai: Eszter a digitális személyiséglopásé, Péter pedig annak az áldozata, hogy Eszter érzelmei az általa digitálisan létrehozott fiktív személynek szólnak, így végül az Eszterhez való közeledési kísérlete azzal végződik, hogy a saját maga által állított csapdába esik bele. Az egyes történetverziók végére a nézô számára kiderül, hogy a videóchat általi egymásra hangolódásuk látszólagos volt, a médium azonnaliságának, a (táv)jelenlét szimulációjának, az intimitás megosztásának (félreértett) effektusa.

Ahhoz, hogy mindkét nézôpontban elmerüljünk, elengedhetetlen a narráció jól megtervezett információadagoló tevékenysége (az elhallgatás és a megmutatás dialektikája) és trükkös manipulációja. Amikor például Eszter búcsúlevelet kap az „angoltanárától” (melyrôl a késôbbiekben megtudjuk, hogy Péter hamisította), az email a korábbiakban megismert, Polgár Csaba által alakított angoltanár hangján „szólal meg”. Az írott szövegnek ez a játékfilmbôl ismert „megszólaltatása”, az online médium „üres helyének” [17] kitöltése az írott szöveg felolvasás általi megtestesítése, ami nemcsak megtéveszti a nézôt, hanem [ahogyan utólag kiderül [az online kommunikáció múködésének a naiv leegyszerúsítése.

Ennek további példájaként vizsgáljuk meg, hogyan jeleníti meg a játékfilmes narráció a videóchatbeszélgetéseket. A szereplôi nézôpontok szétválasztását a felhasználói tapasztalat indokolja. Ezekben a jelenetekben a szereplôk képernyôhasználata a klasszikus kontinuitáson alapuló szerkesztés alapján történik: a megalapozó beállítás és a beszélgetô feleket bemutató kisebb térrészleteket egymás mellé állító beállításokban. Az online mozgóképi telekommunikáció a fiktív tér hiánytalan folyamatosságában jelenik meg. A megalapozó beállítás, a tekintetet követô vágás, beállítás és ellenbeállítás azt ígéri, hogy a történet tere és az online hálózati tér, a szereplôk offline és online identitása hézagmentesen illeszkedik, miközben az offline tér tartalmazza a digitálisat. 

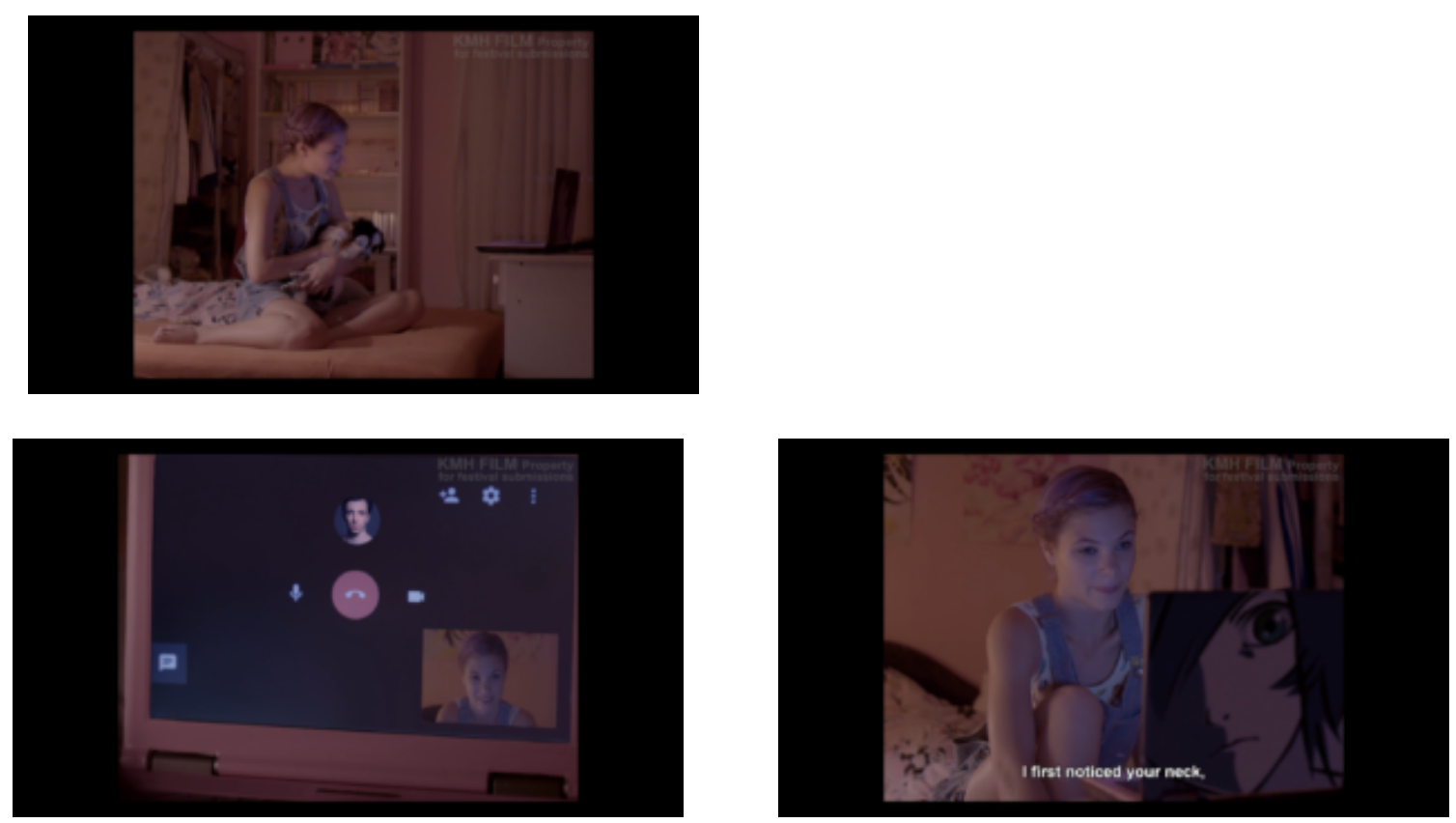

Remélem: a videóchat-beszélgetés térszerkesztése a jeleneten belül

Az egyéni felhasználó nem, csak a játékfilmes narráció képes átlépni az interfésznek a beszélgetô felek által tapasztalt határát és megadni a hiányzó, valós térbeli ellenbeállítást. A két történetverzió videóchates beállításai [igaz, hogy csak a nézó emlékezetében, de [helyreállítják azt a folyamatos filmes teret, amelyet mediálisan a videóchat egyidejú kommunikációja létesített. Pontosabban a Remélem a nézốpont megkettôzôdéséből adódó eltolással, majd ezen optikai nézôpontoknak a nézô általi összeillesztésével az online hálózati teret a szereplôk által belakott filmes térként prezentálja, s ezzel az online mozgóképi kommunikációt az egyazon fizikai térben zajló szemtôl szembeni beszélgetéshez ${ }^{[18]}$ közelíti, mely egy képzeletbeli akciótengely mentén összekapcsolható.
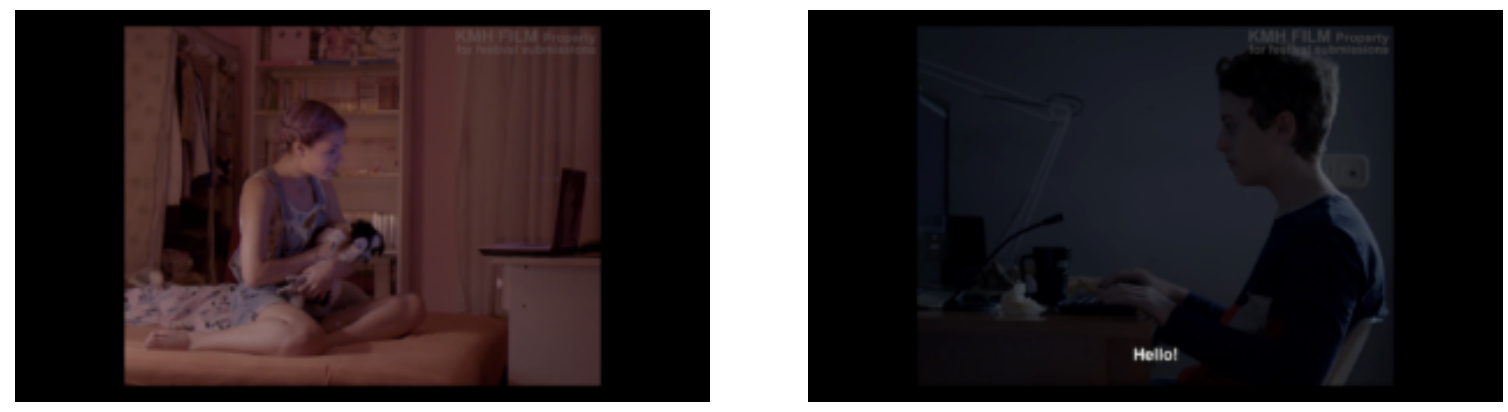

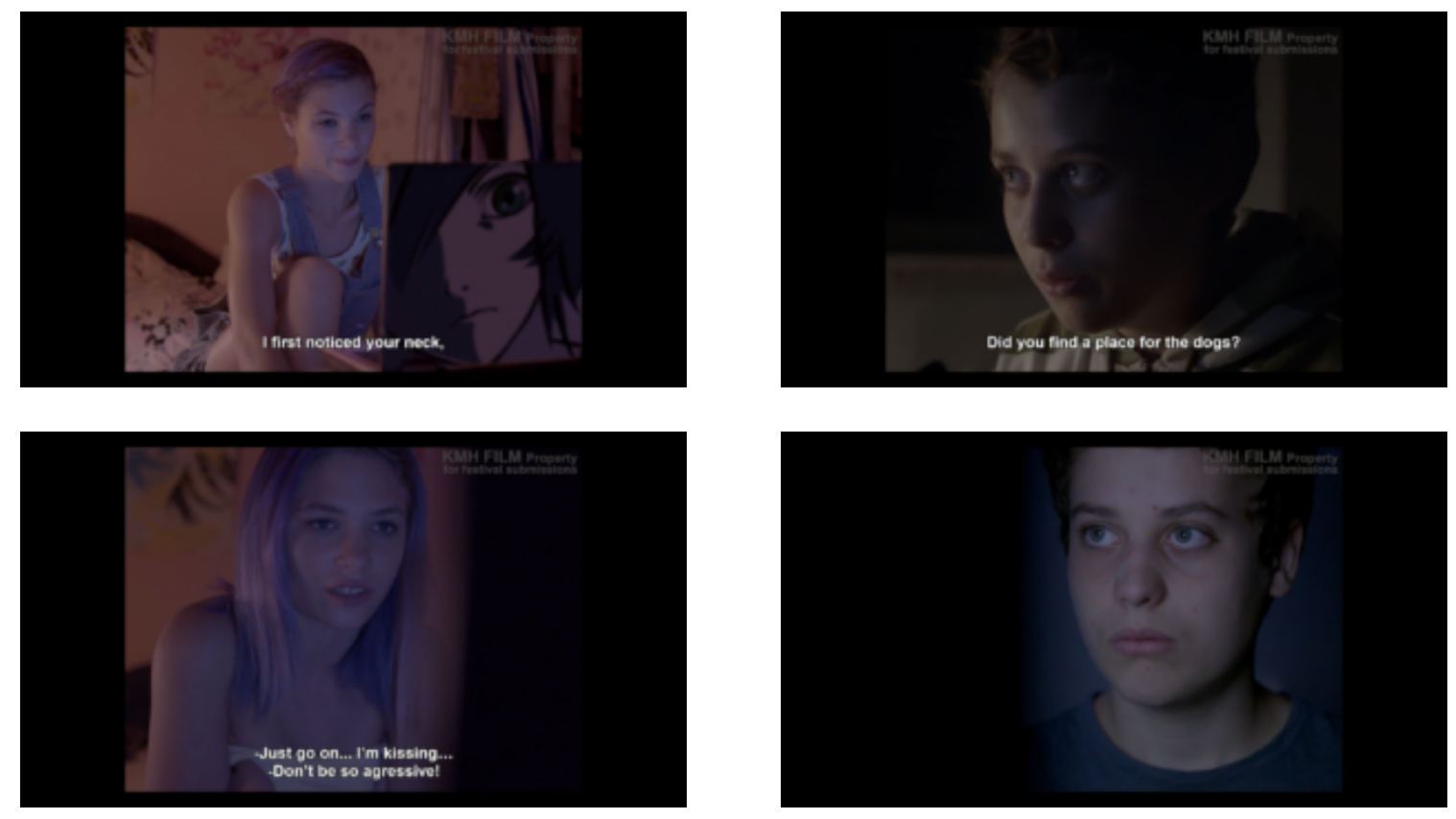

Remélem: a szereplók által belakott filmtér és a videóchat tere

A videóchat egyidejü kölcsönössége a játékfilmben csak akkor tartható fenn, ha a vászon határai megegyeznek az interfészként használt képernyô határaival, de a Remélem-ben ez egy pillanatra sem következik be. Akárhányszor videóchatelnek a szereplők, a filmvászon jól láthatóan bekebelezi és bekeretezi a számítógépes képernyôt, és rendszerint a valós testek árnyékai, részei is megjelennek a keretben. Így az online kommunikáció nem okoz különösebb szakadást a fikcióban, mivel a szereplók fokalizációs tevékenysége a narráció és nem az online médium által strukturált. Ez azt eredményezi, hogy a szereplóket a néző kevésbé tudja az online médium szubjektumaiként érzékelni, a kettójük közti mediatizált interakciót elsôsorban nem egy lapos keret közvetíti, hanem a helyreállított, háromdimenziós hatást előállító filmes tér.

Mindez a történet narráció általi értékelésére is kihatással van: a két történetverzió nem az eltérô perspektívák összeegyeztethetetlenségéból áll elő, hanem a tévedés (megtévesztés) és leleplezés struktúráját követi, amit a nézôi többlettudás hoz létre (csak a nézô tud Péter csalásáról), és technikailag az teszi lehetôvé, hogy Péter nem kapcsolja be a kameráját a videóchatelés közben. Így a film fóként azokhoz a (pedagógiai) diskurzusokhoz kapcsolódik, amelyek a net veszélyeit a visszaélésekben, a rosszindulatú használatban látják, és kevésbé reflektál a médium által felkínált identitás- és szubjektumpozíciókra. A történetben az identitással és a bizalommal való visszaélés váltja ki az internetes zaklatást, ami közvetlen oka a saját testre irányuló erôszaknak.

A filmben a mozgóképi távkommunikáció (vagyis a távoli helyek összekapcsolása) továbbra is a nézô és a narrátor közti kommunikációban múködik biztonságosan, miközben maga a videóchat is a fikciós filmes térhez hasonló szerkezetben és a nézôi töblettudásnak az elôterében kerül a film figyelmébe. A hálózati kommunikáció legerôsebb mozgóképi jelei a filmben a képet szélességében 
kiterjesztô szöveges üzenetek, amelyek a filmvászon szélére íródnak, vagy amikor Eszter alakját elborítják a közösségi médiában megjelenô kommentek, melyeknek súlya alatt végül összeroppan.

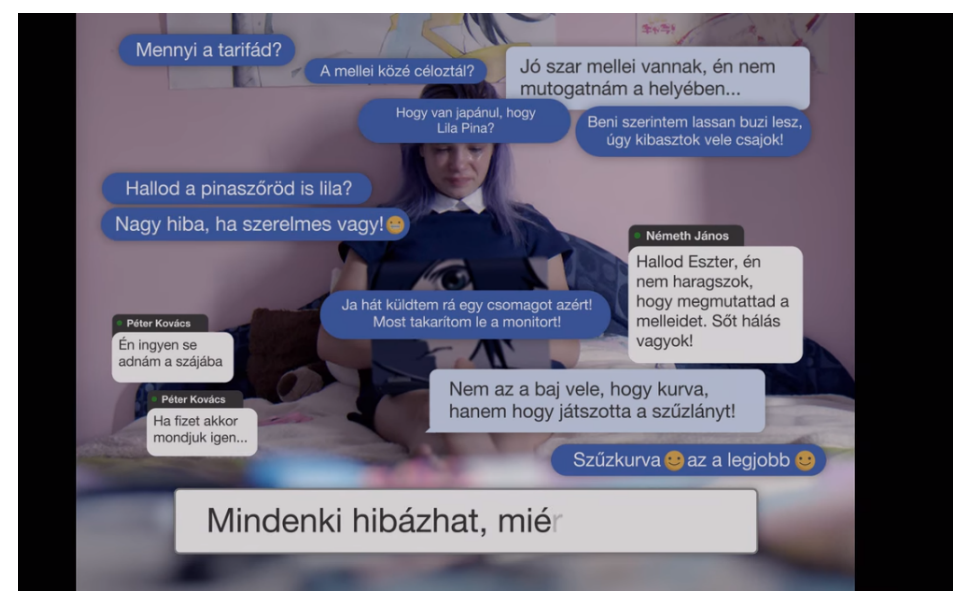

Remélem: online és offline identitás látványos összekapcsolása

\section{FOMO: a mobilképernyô és a filmvászon keresztezôdése}

A FOMO képernyőfilmként kezdôdik, az elsô öt percben egy számunkra ismeretlen felhasználó képernyőn végzett múveleteit látjuk. A nyitószekvenciában a Falka nevú kollektív YouTube-profil létrehozását és terjedô népszerúségét egy olyan montázs mutatja be, amely a filmteret a számítógépes képernyô segítségével hozza létre. Egyrészt a filmvászon helyét átveszi a számítógép képernyője, melyet egy számunkra ismeretlen felhasználó az egéren keresztül manipulál: a stúdió mozgóképes logója (és késóbb a film támogatója, a Nemzeti Filmintézet) a YouTube-on megjelenô nem kívánt reklámként túnik fel, a Falka bemutatkozó videója elôtt, melyet valaki kiterjeszt a teljes képernyốre. Aztán egyenként is bepillantást nyerünk azokba a videókba, melyeket a Falka készített, és korábban már a csatornájukon kilistáztak, felcímkéztek és leírtak: piálás a tanórán, az emberek zaklatása az utcán, stb. Számtalan képi elem és vizuális megoldás emlékeztet arra, hogy még mindig a YouTube-on vagyunk: nemcsak az oldal architektúrája, grafikus megjelenése vagy a múködési problémák (amikor a betöltés leáll), hanem a videómegosztó ismert algoritmusai és „esztétikája” is: a hasonló helyzeteket rögzítô tematikus videók supercut-ja (montázsa), a mobilkamera gyors mozgatásából származó kézikamera-effektus, a kamerába nézés és pózolás. 
Ha mindezt a játékfilm narratív ökonómiája és dramaturgiája szemszögéből nézzük, a nyitószekvencia 【mely a fikció megalapozásának az egyik legfontosabb része, hiszen a fiktív világ szabályaival ismertet meg [egy olyan gyakorító szintagmán ${ }^{[19]}$ keresztül valósul meg, mely a fôszereplôket a közösségi média platformján és a képernyőhasználatukon keresztül mutatja be. A gyakorító szintagma beállításai sem térben, sem idôben nem folyamatosak, az idôkihagyással ismétlődô cselekvéseket, történéseket listáznak, melyeket egy fogalmi jelentésben összegeznek. Itt a Falka nevú fiúbanda YouTube-os profilját és a képernyőn végzett tevékenységét kivonatolják, miközben a különbözố téridőhöz kapcsolódó mozgóképrészletek a képernyôn és a honlap elrendezésében a hálózati tér szimultaneitását példázzák.

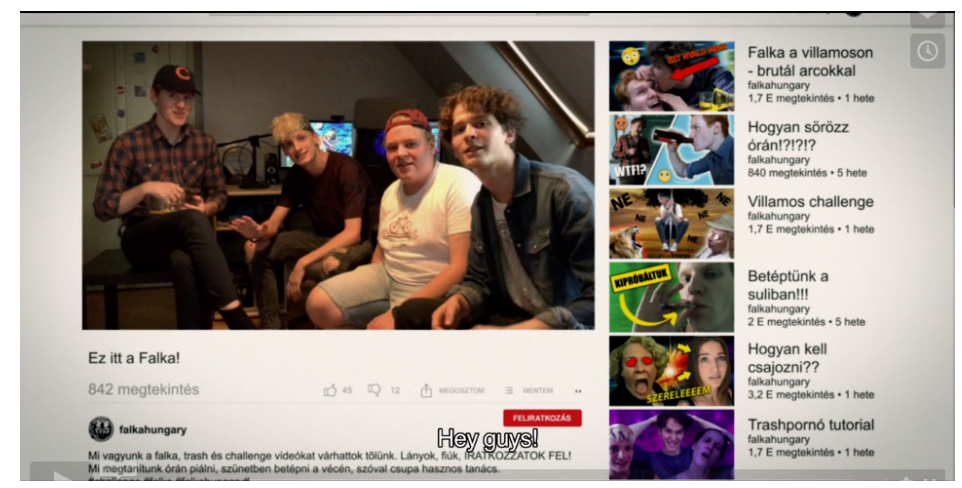

FOMO: a nyitószekvencia képernyófilmes megoldása

Az expozícióban tehát a narráció mintegy átadja a stafétabotot a szereplók közösségi médián belüli önprezentációjának, a challenge videók adatbázisának, melyek elvileg tetszóleges sorrendben megtekinthetôek. A „challenge” a közösségi média beavatási rítusa, a mesebeli vagy hollywoodi akcióhôs próbatételeit helyettesíti, de ebben a kontextusban nem a narratív értelme dominál (vagyis egy életszakasz lezárása, a közösség tagjává válás stb.), hanem a kommunikatív és a performatív aspektusa. A cél a nézettség növelése, mint késôbb kiderül a filmból, a céltudatos kontentgyártás és a megbotránkoztatás; az erôszakos gengszterviselkedést a folyamatos megfelelni vágyás és bizonyításkényszer táplálja. (Ilyen szempontból a challenge mint beavatás sikeressége nem egészen eldönthetô, mivel a közösségi média „közösségébe” való „belépést” folyamatosan ismételni kell a téteket egyre növelô „beavatási rítusokkal”.)

A FOMO tehát nem egyszerúen csak tematizálja a tinédzserek újmédiahasználatának következményeit, hanem imitálja és felmutatja azt a kulturális formát, amelyet ôk használnak. De vajon lehet-e történetet mesélni a pózolós videószelfiken, az önprezentációt elôtérbe helyezô csoportos videóblogokon, challenge-videókon, élô közvetítéseken keresztül? És ha a narráció maga is felveszi ezt a formát, ennek a funkciója az imitáció, a szereplók jellemzése a saját önbemutatásukon keresztül, az új médium bekebelezése a narratív film által vagy az ironikus és reflexív távolságtartás? Milyen átjárás lehetséges a filmvászon és a mobilképernyô, a filmkamera és a mobilkamera között?

A videószelfis „esztétika” [ha lehet így fogalmazni [többé-kevésbé az egész filmre kiterjed: amikor a Falka megjelenik a filmvásznon, mintegy magával hozza a mobilképernyônek ezt a használatát. 
A film elsô részében a versengési szituációk listázása történik, ahogyan a Falka tagjai egymásra licitálnak, ki mer megbotránkoztatóbb és vakmerôbb lenni. Azért vállalják be ezeket, mert mások tekintetének tárgyaiként, a videószelfik szereplóiként tekintenek önmagukra. A folytonos kamerába nézések, az operatôr megszólítása, a pózolások, a kapkodó kézikamerázás a nézônek egy pillanatra sem engedi elfeledni, hogy milyen képi módban vagyunk. A Falka szereplői önmagukat is rendezik, a kamerának szerepelnek, és visszanézik a felvételt: ,jó lett?”, „elkaptad?” kérdezik egymástól, visszaigazolást keresve. Mindez azt eredményezi, hogy a filmben alig vannak klasszikus értelemben vett jelenetek, vagyis olyan részek, amikor a történet nem az élố közvetítés, hanem a filmes „itt és most-ban” bontakozik ki. A filmben dominálnak a videóklipes esztétikát (az elôadásjelleggel és a zenehasználattal is) idézô kézikamerás felvételek, izoláló közelik és gyors montázsok: hiányoznak a megalapozó nagytotálok, a térbeli orientációt segító vágások. A diegetikus jelen idố ilyenkor legfennebb a folyamatos élő közvetítésben tud kibontakozni, és ez akkor is így van, amikor a srácok nem használják a mobileszközeiket.

A film elejérôl vett konkrét példán keresztül szeretném bemutatni, hogy a videószelfi és a játékfilm térideje hogyan kapcsolódik a filmben. Az éjszakába nyúló házibuli bemutatásában a srácok videószelfije, melyet élốben közvetítenek, egy fekete inzert után ékelődik be a filmbe. A kép tájolása (elôször álló, majd fekvô), egy hangszignál, valamint a „LIVE” felirat is felhívja a figyelmet arra, hogy itt egy képen belüli kép vagy mozgóképen belüli mozgókép esetével állunk szemben. Az élố videó a csoport szelfijével kezdődik, melyben bemutatkoznak, majd az elsô és hátsó kamera közti váltással folytatódik az élô közvetítés, a „csajcsekkolás”. Az (ön)filmezés a testhez kapcsolt kamerával tovább folytatódik, a képen kívüli hang irányítja a tekintetet, megnevezi a látottakat, és a kamera hordozójához kapcsolja. ${ }^{[20]}$ A szereplők a képernyôn keresztül mustrálgatják a lányokat 【kifejezetten mulatságos, de a képernyő logikája szempontjából megvilágító, hogy a kamera zoomolásával akarják a képet közelebbrôl látni ahelyett, hogy egyszerúen közelebb lépnének az elôttük lévô látványhoz. Az élố közvetítésnek épp ez a lényegi múködése: megkettôzi, meghasítja a jelen pillanatot, és kép formájában manipulálhatóvá teszi, amire a fizikai találkozás nem adna lehetôséget. A képernyô itt egyszerre szúrô, amely a tekintetet irányítja, valamint maszk és pajzs, mely védőfelületként óvja és eltávolítja a hordozóit azáltal, hogy a nézốk és a nézettek közé ékelôdik. A fiúk a képernyốt arra használják, hogy képként tárgyiasítsák és értékeljék a lányokat, ${ }^{[21]}$ amikor a mobilt elôrekocsizó felvevôgépként használják. A filmben ezt követôen már nem lesz szükség a médiumon belüli médium külön jelölésére, a mobilkamera a szereplôk tekintetének a részévé válik, interiorizálódik, olyannyira, hogy Gergô mentális emlékképeit, melyek az erôszaktevés bizonyos mozzanatait felidézik, ugyanez a képi megjelenítés jellemzi.

Ha azonban figyelmesebben megnézzük ezt a jelenetet, rájövünk, hogy nem minden beállítása a mobilképernyốn keresztül közvetített (ezt jelzi a LIVE felirat eltúnése). A jelenetben kétféle szerkesztés, vágástípus érvényesül: az egyiket maguk a szereplők hajtják végre, amikor a mobiltelefon szelfikamerájáról a hátsó kamerára váltanak. Ez formailag a klasszikus kontinuitás 
elvét megerôsítô, tekintetet követô vágásnak tûnhet: az elsố beállítás megmutatja, ki lát, a második azt, hogy mit lát. Ez az elbeszéló film nyelvtanában az egyik legszorosabb kapocs, „varratnak” tekintett vágás, amely által a nézô a szereplô tekintetén át optikailag is bevonódik, bevarródik a fiktív világba, s ezáltal nem a film nézôjévé, hanem a történet eseményeinek a közvetlen tanújává válik. ${ }^{[22]}$ Valójában a tekintet kontinuitása mégsem jön létre, hiszen itt az elsô beállításban a szereplók önmagukat nézik, és nem azt, amit a második beállítás megmutat. Akárcsak a videóchat esetében, ahol technikailag egyelôre lehetetlen a tekintetváltás - mivel a beszélgető felek vagy a kamerába néznek, de akkor nem látják a másik felet, vagy a másik felet nézik a képernyôn, de akkor nem néznek a másik fél szemébe [] a szelfikamera és a hátsó mobilkamera közti váltás nem biztosítja a nézô és a nézett, a játékfilmben jelölt tér- és idôbeli folytonosságát. (Ebből világossá válik az is, hogy ahhoz hogy a folytonosság létrejöjjön, a tekintetet követô vágásnak egy cezúrát és egy idôbeli eltolást kell bevezetnie, vagyis egymás után bemutatnia azt, ami a történet idejében egyidejưleg történik: valaki néz valamit.)
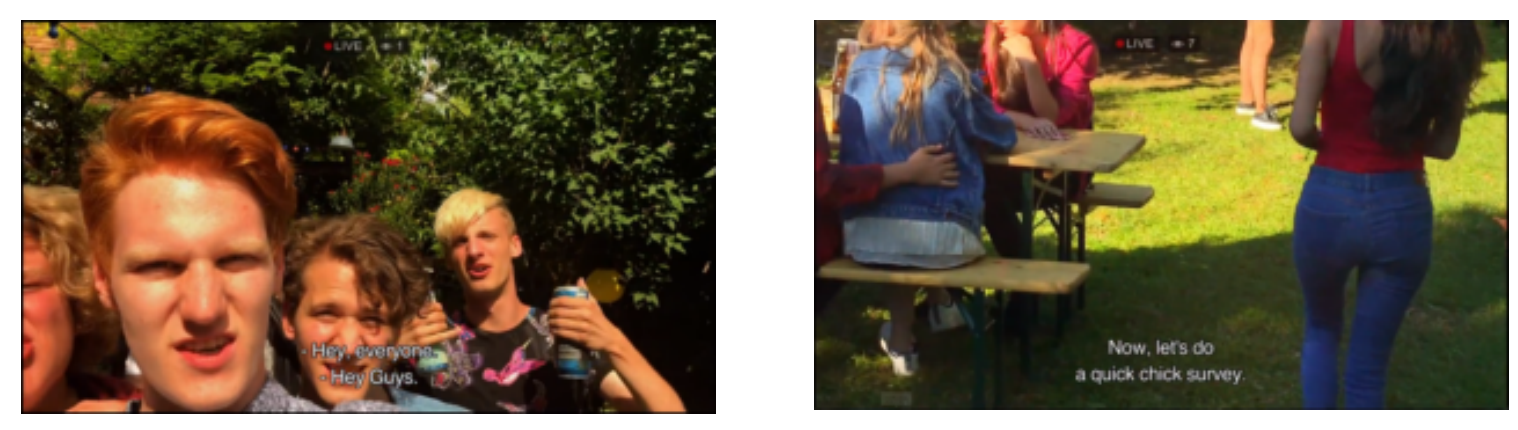

FOMO: a mobilkamerával készített felvételek „vágása”: tekintetet követô vágás?

A sikertelen tekintetet követô vágás miatt van szükség a másik típusú illesztésre, amelynek a szerkesztése kilép a videószelfis módból, amikor összekapcsolja a mobilképernyô közvetített képét és a mobilt tartó fiúknak a közelképét. Ez utóbbi kb. abból a látószögból mutatja a szereplôket, ahonnan a korábbi videószelfi, de mégsem egészen, hiszen magát a mobilt is látjuk a képen. A tekintetük a mobilra szegezôdik, a film nézője pedig egy külsô nézôpontból láthatja, amint elmélyülnek a videószelfis tevékenységükben, miközben a fiktív háromdimenziós teret a képernyố közvetíti számukra. 


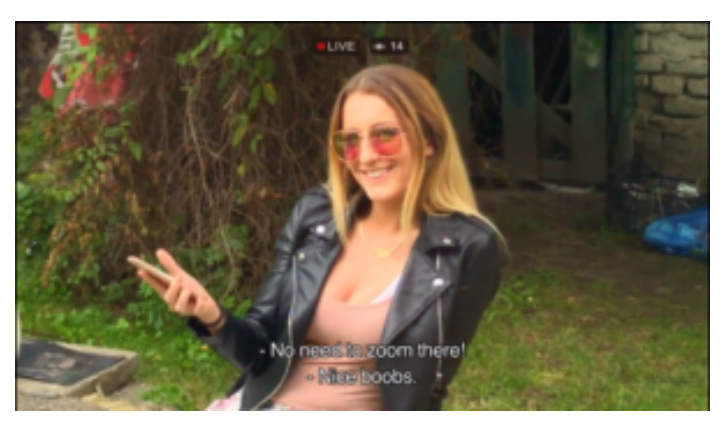

FOMO: filmvászon és mobilképernyő összevarrása.

Ugyanakkor a fenti szekvencia egy másik játékfilmes elbeszélooi eszköz szempontjából is fontossá válik. A mobilképernyő által közvetített képek szubjektívnek tekinthetôek, hiszen a kamera egy testhez kapcsolódik, melynek mozgását, nézésirányát leképezi. A szubjektív szemszög ismertetôjegye, hogy a kamera mintegy megtestesül: a szereplő térbeli helyzetét elfoglalva nemcsak vizuális információt közvetít, hanem a szereplő látásmódjának az imitációja, mimézise. Ezekben a beállításokban nincs jelen a fokalizáló szereplő teste, maga a beállítás kell hogy létrehozza a hiányzó testi jelenlétet. A videószelfi két ponton is átírja a játékfilmes szubjektív szemszög „szabályait”. Egyrészt azzal a játékfilmes szempontból paradox helyzettel szembesít, hogy a szelfikamerás szubjektív beállításban láthatóvá teszi a testet és az arcot, összekapcsolva a kamera elôtti és mögötti teret. Másrészt a szubjektivitásnak ezt a megjelenítését पa mozgóképkészítés szintjén is, nemcsak az észlelés szintjén [a szereplő hatáskörébe utalja. A szubjektív szemszög a játékfilmben azt jelenti, hogy a narrátor a fiktív világ észlelését a szereplôhöz kapcsolja, ráadásul a belsô mélységi fokalizáció olyan tudattartalmakat is megmutathat, amirôl még maga a szereplô sem tud. Ha elfogadjuk, hogy a FOMO mobilképernyő által közvetített beállításai szubjektívek, akkor egy olyan szubjektivitáshoz jutunk, amely nemcsak a szereplốk meghosszabbított „szemén” keresztül közvetítődik, hanem olyan képeken keresztül, melyeknek maguk a szereplốk a szerzôi [23] (készítôi, operatôrei, szerkesztôi, kurátorai) és az elsődleges nézôi is.

Bármennyire is imitálja azonban a film a videószelfis mozgóképi módot, a FOMO címú filmet nem a Falka készítette. Az ellenbeállítás, mely a mobilt tartó fiúkat mutatja, visszahozza a filmbeli tekintet dialektikusságát, miszerint a testtel rendelkezô szubjektumokat nemcsak az határozza meg, hogy tekintettel rendelkeznek, hanem maguk is mások tekintetének tárgyai. Ahogyan Deleyto fogalmaz: „a filmben, a regénytôl eltérôen, a külső és belsô textuális fokalizáció váltogatása vagy egyidejúsége szükséges ahhoz, hogy a szubjektivitást hatékonyan tudja kifejezni” [ 24]. Ugyanezt Sobchack fenomenológiai álláspontból is megerôsíti: „[a] film, egyedülálló módon, [...] objektív betekintést enged a látás szubjektív szerkezetébe, önmagunkba mint egyszerre néző szubjektumokba és látható tárgyakba”. [25] 
A film második részében egyre gyakoribbá válnak azok a játékfilmes eljárások, melyek Gergő ébredô lelkiismeretét, vezeklését mutatják be az elkövetett erôszak után. Ilyenkor a narráció lecsatlakozik a videószelfis önprezentációról, és a filmtechnikailag előállított képek a szereplô belsô látását, mentális tudattartalmait, az ôt mozgató pszichológiai és társadalmi motívumokat hangosítják ki: a film tempója lelassul, a jelenetezés gyakoribbá válik, a mobilképernyő videószelfis módja már nem dominálja a filmvásznat. Ennek leglátványosabb eszköze a kép részleges kimerevítése, amely kétszer is előfordul a filmben, mindkét jelenet a szelfikészítéshez kapcsolódik. Míg a többiek a szelfihez pózolnak, és a testük megmerevedik, eleve képpé alakítva a testüket, a filmkép is megfagy, Gergő pedig szabadon mozog ebben a kimerevített képben. A feltoluló emlékképekre fényképezôdik rá a többszörösen torzított arca - itt egy olyan belsô téridô nyílik meg, melyet nyilvánvalóan nem lehet élőben közvetíteni. Ezt követôen elválik a Falkától, és a saját útját járja, az önigazolás, mentegetôzés, szembesülés, megbánás, beismerés, a barátaival való konfrontáció útját. A narráció a szelfikép mozgóképes meghasításával, szétdarabolásával viszi színre mind a szelfi képi múködésmódját, mind Gergô tudati képeit.
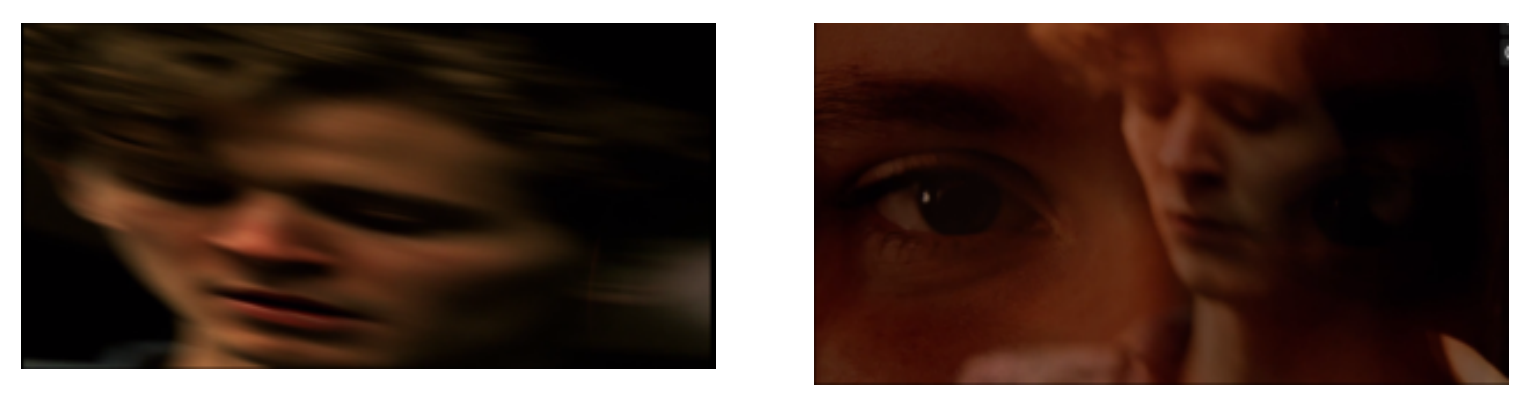

FOMO: a szelfi mozgóképi meghasításából kibomló mentális tér

A FOMO több nézôjének problémát okozott viszont, ${ }^{[26]}$ hogy a fốszereplô identitásában ezt a mediális fordulatot töretlen folytonosságként értse, valószínúleg azért, mert a videószelfis és a képernyőfilmes résszel ellenpontszerúen szembehelyezett játékfilmes mozgóképi megoldások nem kellóen motiválják Gergô megbánását, és hitelesítik azt, hogy ki tud lépni az önmagát és másokat eltárgyiasító képi és identitásparadigmából.

Ugyanez a kérdés a narráció szintjén is megfogalmazható: azzal, hogy a film egy eltérô vizuális rezsim múködésmódját adoptálja és idézi hangsúlyosan, a szereplô identitása már nem csak a narratív közlésen belül artikulálódik, hanem egy másik médiumhoz is kapcsolódik. A szelfinek legalább annyira része az a platform, az a digitális mező, amely kontextualizálja a technologizált ént, a kulturálisan kodifikált testképet, és amely a figyelem és a megosztás olyan ökonómiájának engedelmeskedik, amelyre a narratív filmnek nincs ráhatása. A film zárójelenete egy utolsó kísérletet tesz a két logika összefésülésére. A Falka tagjaival való verekedés után Gergôt látjuk, 
amint egy jelzôlámpánál várakozik. A szubjektív beállítás a cipó orráról indul, az utcai szemetet és a várakozó járókelôket pásztázva a repülô madarakig, az épületek tetejéig emelkedik, utolsó állomása pedig Gergó közelije. A lehetetlen kameramozgás összekapcsolja a szubjektív tekintetet a tekintet birtokosának arcközelijével, akárcsak a videószelfi esetében. Beállítások sorozata következik, melyekben a narráció összevarrja Gergô (nem a kamerába nézô) tekintetét a járókelôk kamerába nézô tekintetével. Mintha először látna a képernyô közvetítése nélkül, maga is tekintetek tárgyává válik, amit a játékfilm médiuma hoz létre.
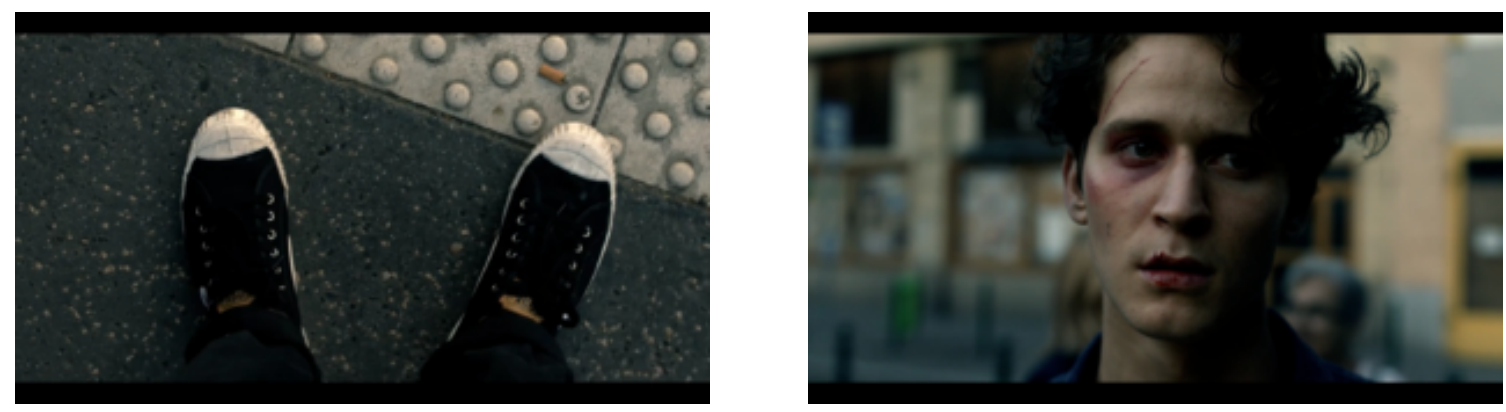

FOMO: A zárójelenet lehetetlen kameramozgásának kezdô és végsô állomása, Gergố cipőjétôl az arcáig

\section{Szép csendben: a zene és a testek érintkezése}

A Szép csendben legerôteljesebb gesztusa a narrátori mindentudás visszavonása: épp a legfontosabb eseménnyel, a feltételezett visszaéléssel kapcsolatban válik kérdésessé, hogy az valóban megtörtént-e [maguknak a szereplőknek is értelmezniük kell az erre vonatkozó jeleket, a néző pedig többnyire ahhoz fér hozzá, ahogyan az ô észlelô-felfogó horizontjukon megjelenik az adott esemény. Elôször úgy tûnik, hogy a fôszereplô Dávid, akinek a nézôpontja a leghangsúlyosabb, egyszerúen nincs jelen a megfelelô helyen és pillanatban, amit hallgatózással, leskelődéssel próbál kompenzálni. A film végsố tanulsága mégis az, hogy a testi vagy távjelenlét nem ad igazabb vagy teljesebb hozzáférést a traumatikus, a szubjektum számára megnevezhetetlen, kategorizálhatatlan eseményekhez.

Bár a film fiktív világában is jelen vannak az okoseszközök (Dávid videóchaten beszél az Amerikában új családjával élố apjával, barátja a vacsoraasztalnál a mobiltelefonján Sütô-drámákat olvas!), a telekommunikáció és a digitális identitás nem kap jelentôs szerepet sem a történetben, sem a narrációban. Az a hangfelvétel, melyet a szereplôk azért készítenek, hogy az abúzusra utaló jeleket rögzítsék, inkább fenntartja és tovább növeli a bizonytalanságot. Az okostelefonnal rögzített hangfelvétel úgy múködik, mint a Nagyítás (Blow Up. Michelangelo Antonioni, 1966) fotója vagy a Magánbeszélgetés (The Conversation. F.F. Coppola, 1974) poloskával rögzített felvétele: a rögzítés 
által létrehozott jelenlét nem ad egyértelmú kulcsot a rögzített valóság megértéséhez. A rögzítésnek a ténye, a felvétel létezése megijeszti a visszaéléssel vádolt tanárt, a szereplôk viszont eltéró értelmezéseket kapcsolnak hozzá. Dávid belehallja a nemi abúzusra utaló jeleket, barátnôje számára a felvétel nem árulkodik semmilyen rendellenes tényrôl. A múvészfilmre jellemző ambiguitás abból ered, hogy a dolgok nem leválaszthatóak arról a tekintetrôl, amelyen keresztül nézzük ôket.

Ellentétben a két másik filmmel a Szép csendben narrációja az eseményeket nem egy másik technikai médium bevonásával magyarázza, hanem egy olyan narratív többletet hoz létre, mely a történet kihagyásait, hézagait értelmezhetôvé teszi. Ez a történeten egyszerre túlmutató és azt megelőlegező sík a zenéhez kapcsolódik, és nemcsak a diegetikus és nondiegetikus zenehasználatban valósul meg, hanem a film képi dimenziójában is, így a történet értelmezését egy új szintre emeli. Még mielôtt a gyanú felmerülne, és Dávid nyomozó, jelfejtô tevékenysége kibontakozna, a film a hegedúhúrok befúzésével kezdôdik, amit a zenekar bemelegítố hangolása követ. Mindkét tevékenység a hangok és a testek szoros viszonyát viszi színre. A testek rezgéseket, tehát hangokat tudnak kibocsátani, de maguk is felfogják és továbbítják a hangok „érintését”. A zeneiskolai karmester (a visszaéléssel gyanúsított) Frici bának a pedagógiai módszere azon alapul, hogy a zenész teste a hangszer meghosszabbítása, kiterjesztése. Merev izmokkal nem lehet finoman játszani, a testi érintéseknek az a szerepük, hogy elókészítsék a zenész testét a zenére, amely szintén érintéssel jön létre.

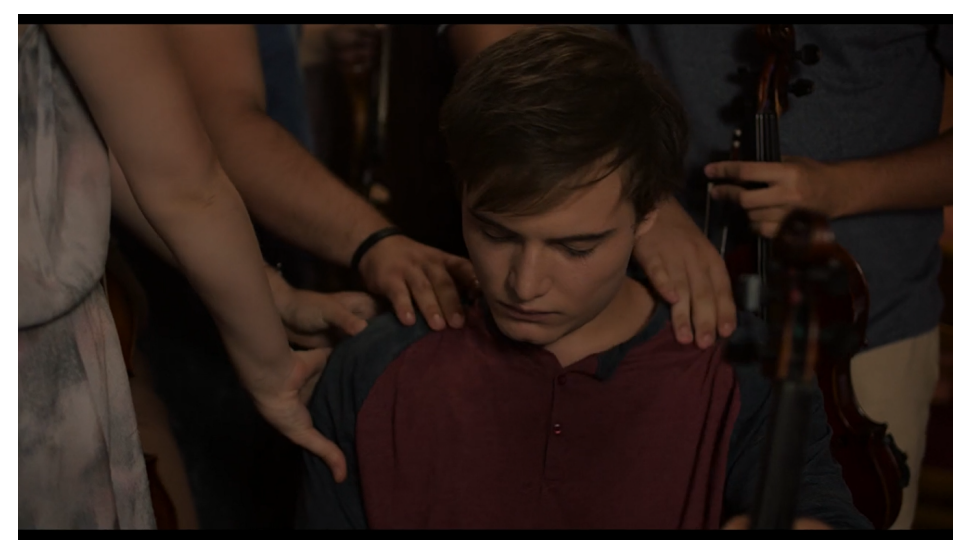

Szép csendben: a testek kommunikációja 
A zene a filmben olyan szupermédium, amely a testek egymásra hangolódásán keresztül kommunikál [nincs szükség digitális hálózatra és infrastruktúrára, hogy a kommunikáló felek összekapcsolódjanak. A zene nem verbális, szavak, kategóriák, fogalmak elốtti kommunikációja azonban extrém módon ki is szolgáltatja a testeket minden érintésnek (a hang elól nem lehet elbújni ahhoz hasonlóan, ahogyan becsukjuk a szemünket, hogy ne lássunk valamit). Az együttzenélés kétféle értelemben is átadás: a testek átadása a zenének és a megszólaltatott zene átadása, ráadásul a lineáris kommunikációval ellentétben, ahol a felek egymást követôen egymásra reagálnak, itt mindez szimultán módon történhet a testek és hangszerek sokszólamúságában. A zenélésben és a zenehallgatásban (mely szinkrón módon valósul meg) az egész test részt vesz, a testek egyszerre kibocsátói, közvetítői és felfogó felületei a hangoknak mint rezgéseknek.

A film expozíciós részének minden epizódja egy olyan világot vázol fel, amelyhez a szereplốk a hangok és az érintés útján kapcsolódnak, és egymásra is ezen keresztül vannak hatással: a zenekari tagok finoman masszírozzák Dávid vállát, hogy el tudjon lazulni, Dávid és barátja élô zenével kísérik a Trash TV-ben látott horrorjelenetet, úton hazafelé a jelzólámpa ritmikus fényjelzéseit zeneként fordítja le, és játékosan követi az ugrálásaival, barátnőjével a gerle búgását utánozva kommunikálnak az ablakpárkányra repült madárral, Frici bá „hangtalanul” labdázik Nórival. A testeknek az érintéseken és a zenén keresztül történő „kommunikációja” visszatéríti a terminust az etimológiai értelméhez. Eszerint a kommunikáció nem más, mint adás, ajándékozás, átvitel. ${ }^{[27]} \mathrm{A}$ kommunikáció mint fizikai kontaktuson alapuló átadás vagy csere ebben az értelemben is valamilyen közvetítô közeget, azaz médiumot feltételez. A testek közti tér nem légüres tér, hanem azon materiális kötelékek szövedéke, melyek a testet is porózussá, áthatolhatóvá teszik.

Az együtt rezonálás azonban nem jár együtt a fogalmi értelemben vett megismeréssel: amikor a testek ilyen érintkezését le akarjuk fordítani a szándékok, vágyak, tettek kiismerhetôségére, a remediatizáció nem lesz sikeres. A filmnek olyan narratív kódok szerinti olvasata, amely a szereplői tudatokat áthatolhatóként tételezi, kudarcot vall, mivel a szereplôk önmaguk számára sem olvashatóak. (Gondoljunk csak Nóri viselkedésére, aki először diáktársának jelzi a tanár nem helyénvaló közeledését, aztán az anyja és a vizsgálati nyomozó elótt az egészet letagadja, de a tanár közeledését azért utasítja vissza, mert féltékenységében ezzel zsarolja.) A szétszálazhatatlan érzéseknek és reakcióknak a kavalkádja 【kiszolgáltatottság, hatalom, féltékenység, rivalizáció, megbántottság, vonzódás [aSzép csendben történetét a rezdülésszerú történések szintjére transzponálja: az eseményeknek azért nincs végleges helyük és értékük a történetben, mert maguk a szereplôk sem értik, hogy mi történik velük, és a narráció nem hajlandó ezt a konfúziót és zavarodottságot kisimítani, feloldani. Mindez azzal a belátással jár együtt, hogy a mozdulatok, érintések, szavak jelentése nem egyszerúsíthető a végrehajtójuk intencióira, inkább a kommunikációt lehetôvé tevô, testek közötti tér rezonanciáiban, visszaverôdéseiben és a testek ráhangolódásában közvetítődik.

Így az is érthetôvé válik, hogy a narráció miért utasítja vissza a „tényleges” történések megmutatását. Ennek nemcsak az lehet a magyarázata, hogy a nézó voyeur pozícióját 
ellehetetlenítse - ahogy a rendezô nyilatkozta [ hanem az is, hogy a traumatikus esemény egész egyszerúen megmutathatatlan, legalábbis a filmképnek abban a realista paradigmájában, mely töretlen folytonosságot tételez látás és tudás között. Ehelyett a narráció arra tesz kísérletet, hogy a nézô testét a szereplôk testéhez hasonló, érintésekre fogékony helyzetbe hozza, a haptikus képeken keresztül a nézố testét is megérintse. A hangszerek elmosódott közelképeinek a taktilitása találkozik a húrok megfeszítésével kiváltott hangok rezgésével. A képi és hangi sávban létrejövô érintések közös felülete a nézô teste. (Csak a nézô testén keresztól tudnak a képek és a hangok „érintkezni”.) Az érzéki képi megoldások olyan narratív többletet hoznak létre, mely minden kommunikáció anyagiságára tereli a figyelmet: a film nézése nem elsôsorban a megfejtésre váró jelek és információk feldolgozása, hanem a testi létezésbe való bevonás a film „testének” érzékelésén keresztül.

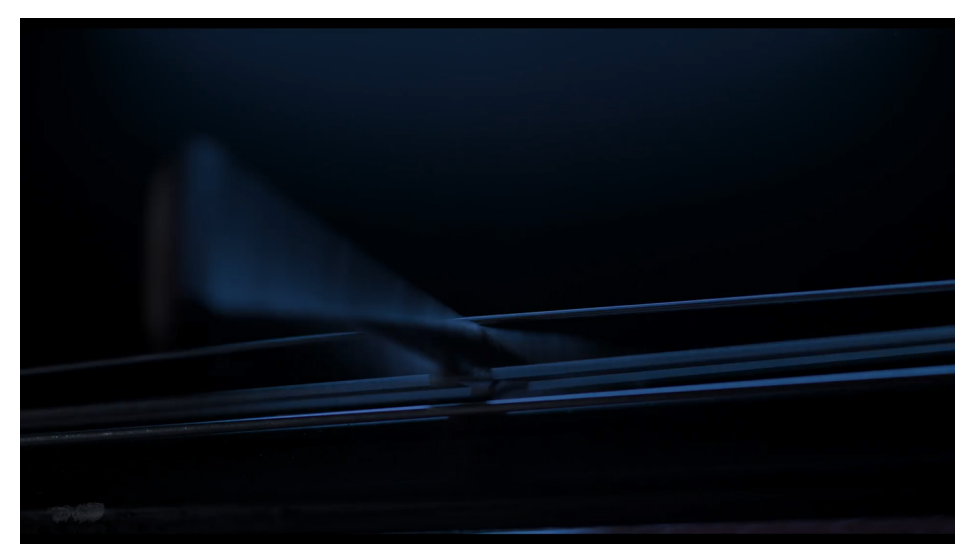

A hangszertestek elmosódott közelije (Szép csendben)

\section{Összegzés}

Tanulmányomban annak a fordulatnak egyik lehetséges megközelítési módját vizsgáltam, amelyet a mozgóképek anyagszerú használata és birtoklása váltott ki, miszerint már nemcsak a mozgóképélmény részesei vagyunk a moziban, hanem például kommunikációs eszközként használjuk azokat. Ha a kortárs játékfilmet a hálózati telekommunikáció narratív újrakeretezésére tett kísérletként értelmezzük, óhatatlanul szembesülünk a két médium eltérő ágenciái, észlelési viszonyai, feldolgozási módjai közti különbséggel. Itt csak azokat a hatásokat vizsgáltam, amelyeket az online telekommunikáció szolgálatába állított mozgóképek narrációba való beemelése vált ki: a fiktív tér és idô konstitúciójában, a játékfilmes karakteridentitásban, valamint az elbeszélhetôség tekintetében. A Remélem a nézôpontok ütköztetésével és a nézôi többlettudással játékfilmesíti a videóchat mediális effektusait, míg a FOMÓ-ban a szereplôket két eltérô médium szubjektumaiként is elhelyezhetjük. A Szép csendben a szereplói tudatok áthatolhatatlanságával a történet elbeszélhetôségébe vetett kételyt fogalmazza meg, és visszatéríti a nézôt a testi létezés érzéki átéléséhez. 


\section{Jegyzetek}

1. Lásd például Gyenge Zsolt írását, aki a három filmet épp ez alapján hasonlítja össze. Gyenge Zsolt: Testek a tilosban. Magyar \#metoo filmek. Filmvilág, 2020. február. URL: https://filmvilag.hu/xista_frame.php?cikk_id=144.20

2. Kivéve, ha a párhuzamos szerkesztés osztott képernyốn valósul meg, ami a történéseket nemcsak egyidejúként reprezentálja, hanem egyidejú megtapasztalásukat is lehetôvé teszi.

3. Lásd ehhez Tom Gunning: Fritz Lang Calling: the telephone and the circuits of modernity. In Allegories of Communication. Intermedial concerns from cinema to the digital. Szerk. John Fullerton és Jan Olsson. Róma, John Libbey Publishing, 2004. 19-38.

4. Ennek egyik szép kortárs példája Alejandro González Inárritu Bábel (2006) címú filmje, ahol nemcsak az időfelbontás rendezi újra a történet befogadását, hanem az a mód is, ahogyan a helyek a vágáson keresztül „érintkeznek”: a marokkói kis falutól Tokió zsúfolt nagyvárosi terein át a mexikói sivatagig és a kaliforniai álomotthonig kibontakozó globális távlat egyrészt a nyugati turisták múltbeli utazásainak „nyomain” keresztül bontakozik ki, a történet jelen idejében pedig a távkommunikáció kapcsolja össze a politikai és társadalmi határok által elválasztott szereplôket. Lásd ehhez Elizabeth S. Anker: In the Shadowlands of Sovereignty: The Politics of Enclosure in Alejandro González Iñárritu's Babel. University of Toronto Quarterly, 82.4 (2013. ốsz), 950-973.

5. Legkorábbi példaként a Jennicamet szokás említeni: 1996-ban Jennifer Ringley, egy fốiskolás lány webkamerát szerelt a számítógépére, és a kollégiumi szobájából napi 24 órán keresztül közvetített bizonyos idôközönként felvett állóképeket. Lásd ehhez Victor Burgin: Jenni’s Room: Exhibitionism and Solitude. In uô: The Remembered Film. London, Reaktion Books, 2004. 44-57.

6. A videóblogos formátumot a websorozatok is kisajátították, amikor például videóblogként címkéztek profi stúdiók és színészek által készített fikciós websorozatokat (például a Lonelygirl15 és az Emokid21 esete). Lásd Glen Creeber: It's not TV, it's online drama: The return of the intimate screen. International Journal of Cultural Studies, 14.6 (2011), 591-606.

7. Marsha Kavka: From the „Belfie” to the Death-of-Me: The Affective archive of the self(ie). In Imaging Identity. Text, Mediality and Contemporary Visual Culture. Szerk. Johannes Riquet, Martin Heusser. PalgraveMacMillan, 2019. 35-60. 35.

8. Aaron Hess: The Selfie Assemblage. International Journal of Communication, 9 (2015), 1629-1646. 1630-31.

9. Simor Kamilla ennek a viszonynak az aktív pólusait így határozza meg: „egyszerre nézzük magunkat, miközben megmutatjuk magunkat másoknak, és egyszerre mutatjuk meg magunkat másoknak, miközben önmagunkat nézzük". Simor Kamilla: A késô modern kori hadviselés dokumentumfilmes ábrázolásának lehetôségei és a videószelfik használatának percepciós összefüggései. Apertúra, 2021. ôsz (megjelenés elốtt).

10. Bódy Gábor: Végtelen kép és tükrözôdés. In uố: Végtelen kép. Budapest, Pesti Szalon, é. n. 295-299.

11. Rosalind Krauss: Video: The Aesthetics of Narcissicm. October, 1. (1976. tavasz), 50-64. 61. [Magyarul: Video [] a nárcizmus esztétikája. In Bán András et al. (szerk.): A videó világa. Videómúvészet. Budapest, Népmúvelési Intézet, 1983.]

12. Christian Ferencz-Flatz: Tíz tétel a videóchat realitásáról. Egy fenomenológiai leírás. Ford. Gyenge Zsolt. Apertúra, 2021. tél. URL: https://www.apertura.hu/2021/tel/ferencz-flatz-tiz-tetel-a-videochat-realitasarolegy-fenomenologiai-leiras/

13. Paul Young: Cinema Dreams Its Rivals. Media Fantasy Films from Radio to the Internet. University of Minnesota Press, 2005. 
14. Vivian Sobchack: „Én, engem és magam”: A home movie kísérteties hatásáról. Ford. Simor Kamilla. Apertúra , 2021. tél. URL: https://www.apertura.hu/2021/tel/sobchack-en-engem-es-magam-a-home-moviekiserteties-hatasarol/

15. Goffman, Erving: Az én bemutatása a mindennapi életben. Ford. Berényi Gábor. Budapest, Pólya Kiadó, 2000.

16. Finola Kerrigan [Andrew Hart: Theorising digital personhood: a dramaturgical approachJournal of Marketing Management, 32. 17-18 (2016)

17. Fabienne Liptay: Üres helyek a filmben. A kép és a képzelet összjátékáról. Ford. Fám Erika. Apertúra, 2008. nyár. URL: https://www.apertura.hu/2008/nyar/liptay-ures-helyek-a-filmben-a-kep-es-a-kepzeletosszjatekarol/

18. Sidoni három pontban összegzi a két kommunikációs szituáció közti különbségeket. 1. A társadalmi térhasználat konnotációinak nagy része elveszik az online közvetítésben. Míg a valós térben a beszélgetőfelek térhasználata (például a kettőjük közti távolság) „kölcsönösen egyeztetett”, a videóchatben a távolság rögzített, egy olyan „kimerevített” (frozen) térben, ahol a térbeli elhelyezés, a távolság önkényesen megállapított, nincs interszubjektív jelentése. 2. Az online kommunikáció megnehezíti az intencionális és nem intencionális kommunikációs aktusok olvasását. A testhelyzet, mozdulatok, gesztusok nemverbális kommunikációjának nagy része képen kívül marad, és az intencionális és nem intencionális aktusok közti különbséget tovább bonyolítja az a reflexív megkettőzôdés, hogy a beszélő a chatablakban megjelenô testének a nézője is. 3. A szemkontaktus lehetetlensége miatt a videóchatben a virtuális tekintetváltás nem jöhet létre. Maria Grazia Sindoni: Digital Apocalypses: Verbal or Visual Decline? Mantichora, 2. 2012. december. 82-94.

19. Christian Metz: Az elbeszélő film mondattana. In Hankiss Elemér (szerk.): Strukturalizmus. (1. kötet), Budapest, Európa, 1966. 225-232.

20. Hasonlóképpen a VR-hoz, ahol a VR-szemüvegen keresztül megjelenő kép a test fizikai helyzetét követve a nézó szeméhez és mozgó testéhez igazodik.

21. Ebbôl majdhogynem levezethetô az, amikor Gergô [a mobilképernyôjén keresztül nézve és rögzítve a ,jelenetet” [megerôszakolja az öntudatlan Lillát.

22. Dayan, Daniel: A klasszikus film mesterkódja. Ford. Fürstner Klára és Füzi Izabella. Apertúra, 2005. ôsz. URL: https://www.apertura.hu/2005/osz/dayan-a-klasszikus-film-mesterkodja/

23. Ahogyan ez megmutatkozik a nemi erôszakról készült videó mustrálgatása közben, melyet ,jó anyagnak” minôsítenek.

24. Celestino Deleyto: Fokalizáció a filmi elbeszélésben. Ford. Ferencz Anna. Apertúra, 2005. ôsz. URL: https://www.apertura.hu/2005/osz/deleyto-fokalizacio-a-filmi-elbeszelesben/

25. Vivian Sobchack: A vászon és a képernyő színtere. Ford. Kaposi Ildikó. Metropolis, 2017/2. 8-24.

26. A kritikák a film zárlatában a búnhődés elégtelenségét, a megoldás antikatartikus jellegét emelték ki (Rakita Vivien: Áldozathibáztatás lvl 1000. Filmtett, 2019. október 4. URL:

https://www.filmtett.ro/cikk/aldozathibaztatas-lvl-1000-hartung-fomo-kritika/), egy másik kritika szerint a film „bántóan nincs lezárva”, az utolsó hídjelenetben kevéssé hihetô Gergô „öntudatra ébredése” (Inkei Bence: Nem kényelmes szembesülni azzal, mi lett a tinédzserekból. 24.hu, 2019. október 5. URL: https://24.hu/kultura/2019/10/05/fomo-megosztod-es-uralkodsz-film-kritika/).

27. Lásd bôvebben: John Guillory: A médiafogalom eredete. Ford. Berze András, Nagy Ambrus és Szvetnik Péter. Apertúra, 2012. tavasz. URL: https://www.apertura.hu/2012/tavasz/guillory-a-mediafogalomeredete/ 


\section{Irodalomjegyzék}

- Anker, Elizabeth S.: In the Shadowlands of Sovereignty: The Politics of Enclosure in Alejandro González Iñárritu's Babel. University of Toronto Quarterly, 82.4 (2013. ôsz), 950-973.

- Bódy Gábor: Végtelen kép és tükrözôdés. In uô: Végtelen kép. Budapest, Pesti Szalon, é. n. 295299.

- Burgin, Victor: Jenni’s Room: Exhibitionism and Solitude. In uô: The Remembered Film. London, Reaktion Books, 2004. 44-57.

- Creeber, Glen: It's not TV, it's online drama: The return of the intimate screen. International Journal of Cultural Studies, 14.6 (2011), 591-606.

- Dayan, Daniel: A klasszikus film mesterkódja. Ford. Fürstner Klára és Füzi Izabella. Apertúra, 2005. ôsz. URL: https://www.apertura.hu/2005/osz/dayan-a-klasszikus-film-mesterkodja/

- Deleyto, Celestino: Fokalizáció a filmi elbeszélésben. Ford. Ferencz Anna. Apertúra, 2005. ôsz. URL: https://www.apertura.hu/2005/osz/deleyto-fokalizacio-a-filmi-elbeszelesben/

- Ferencz-Flatz, Christian: Tíz tétel a videóchat realitásáról. Egy fenomenológiai leírás. Ford. Gyenge Zsolt. Apertúra, 2021. tél. URL: https://www.apertura.hu/2021/tel/ferencz-flatz-tiztetel-a-videochat-realitasarol-egy-fenomenologiai-leiras/

- Goffman, Erving: Az én bemutatása a mindennapi életben. Ford. Berényi Gábor. Budapest, Pólya Kiadó, 2000.

- Gunning, Tom: Fritz Lang Calling: the telephone and the circuits of modernity. In Allegories of Communication. Intermedial concerns from cinema to the digital. Szerk. John Fullerton és Jan Olsson. Róma, John Libbey Publishing, 2004. 19-38.

- Gyenge Zsolt: Testek a tilosban. Magyar \#metoo filmek. Filmvilág, 2020. február. URL: https://filmvilag.hu/xista_frame.php?cikk_id=14420

- Hess, Aaron: The Selfie Assemblage. International Journal of Communication, 9 (2015), 1629-1646. 1630-31.

- Inkei Bence: Nem kényelmes szembesülni azzal, mi lett a tinédzserekböl. 24.hu, 2019. október 5. URL: https://24.hu/kultura/2019/10/05/fomo-megosztod-es-uralkodsz-film-kritika/

- John Guillory: A médiafogalom eredete. Ford. Berze András, Nagy Ambrus és Szvetnik Péter. Apertúra, 2012. tavasz. URL: https://www.apertura.hu/2012/tavasz/guillory-a-mediafogalomeredete/

- Kavka, Misha: From the „Belfie” to the Death-of-Me: The Affective archive of the self(ie). In Imaging Identity. Text, Mediality and Contemporary Visual Culture. Szerk. Johannes Riquet, Martin Heusser. Palgrave-MacMillan, 2019. 35-60.

- Kerrigan, Finola \Hart, Andrew: Theorising digital personhood: a dramaturgical approach. Journal of Marketing Management, 32. 17-18 (2016)

- Krauss, Rosalind: Video: The Aesthetics of Narcissicm. October, 1. (1976. tavasz), 50-64. 61. [Magyarul: Video [a nárcizmus esztétikája. In Bán András et al. (szerk.):A videó világa. Videómúvészet. Budapest, Népmúvelési Intézet, 1983.]

- Liptay, Fabienne: Üres helyek a filmben. A kép és a képzelet összjátékáról. Ford. Fám Erika. Apertúra, 2008. nyár. URL: https://www.apertura.hu/2008/nyar/liptay-ures-helyek-a-filmbena-kep-es-a-kepzelet-osszjatekarol/

- Metz, Christian: Az elbeszélő film mondattana. In Hankiss Elemér (szerk.): Strukturalizmus. (1. 
kötet), Budapest, Európa, 1966. 225-232.

- Rakita Vivien: Áldozathibáztatás lvl 1000. Filmtett, 2019. október 4. URL: https://www.filmtett.ro/cikk/aldozathibaztatas-lvl-1000-hartung-fomo-kritika/)

- Simor Kamilla: A késô modern kori hadviselés dokumentumfilmes ábrázolásának lehetôségei és a videószelfik használatának percepciós összefüggései. Apertúra, 2021. ôsz (megjelenés eloott).

- Sindoni, Maria Grazia: Digital Apocalypses: Verbal or Visual Decline? Mantichora, 2. 2012. december. 82-94.

- Sobchack, Vivian: „Én, engem és magam”: A home movie kísérteties hatásáról. Ford. Simor Kamilla. Apertúra, 2021. tél. URL: https://www.apertura.hu/2021/tel/sobchack-en-engem-esmagam-a-home-movie-kiserteties-hatasarol/

- Sobchack, Vivian: A vászon és a képernyô színtere. Ford. Kaposi Ildikó. Metropolis, 2017/2. 8-24.

- Young, Paul: Cinema Dreams Its Rivals. Media Fantasy Films from Radio to the Internet. University of Minnesota Press, 2005.

\section{Filmográfia}

- A lé meg a Lola (Lola Rennt. Tom Tykwer, 1998)

- A vihar kapuja (Rashomon. Akira Kuroszava, 1950)

- Bábel (Babel. Alejandro González Inárritu, 2006)

- FOMO Megosztod és uralkodsa(Hartung Attila, 2019)

- Keresés (Searching. Aneesh Chaganty, 2018)

- Magánbeszélgetés (The Conversation. F.F. Coppola, 1974)

- Nagyítás (Blow Up. Michelangelo Antonioni, 1966)

- Profile (Timur Bekmambetov, 2018)

- Remélem, legközelebb sikerül meghalnod (Schwechtje Mihály, 2018)

- Szép csendben (Nagy Zoltán, 2019)

- Unfriended: Dark Web (Stephen Susco, 2018) 
(c) Apertúra, 2021. nyár | www.apertura.hu

webcím: https://www.apertura.hu/2021/nyar/fuzi-a-kepernyo-es-a-filmvaszon-hibridizacioja-avideochat-es-a-videoszelfi-jatekfilmes-idezese-remelem-legkozelebb-sikerul-meghalnod-fomo\% $2 \% 80 \% 92$-megosztod-es-uralkodsz-szep-csendben/

https://doi.org/10.31176/apertura.2021.16.4.5

\section{Q)opertúro}

